\title{
The employers' view of “work-ready” graduates: A study of advertisements for marketing jobs in Australia.
}

\begin{abstract}
This study of job advertisements extends our understanding of how employers, rather than researchers, describe the specific skills and attributes sought in candidates for employment in graduate marketing roles in Australia. The paper presents the findings of a content analysis of 359 marketing job advertisements downloaded in 2016, in two periods six months apart, from the dominant job finding website in Australia, seek.com.au. This data offers detailed primary records authored by employers, and sets the research apart from most studies, which rely on generic variables imposed by academics, despite the mooted gap between academia and the business sector. The most demanded attributes included motivation, time management, communication skills, and digital marketing experience. This raises questions about the purpose of a degree, and whether marketing curricula are fit for purpose. The paper explores these findings and other preconditions for being "work-ready”, and the study contributes to the underdeveloped employability research from Australia.
\end{abstract}

Keywords: job advertisements, marketing, employability, graduates, Australia, employer needs, university curricula, syllabi.

Acknowledgement: The authors would like to acknowledge the support of Griffith Business School at Griffith University for providing funds for this research study. 


\section{Introduction}

Graduate employability is a relatively new topic of academic research, with the bulk of studies published after the year 2000. The rise of employability research accelerated with the global financial crisis of 2007-2011, and the weak job market that has followed since. Having a university degree was once a surety for securing a job, but this is no longer the case, as reflected in an unemployment rate of almost 30 per cent of business school graduates in Australia. In 2015, only 70.8 per cent of bachelor of business graduates actively seeking fulltime work had found full-time jobs within four months of completion of their degree (Graduate Careers Australia [GCA], 2015). Although higher education has a larger purpose than mere employability (Clarke et al., 2006; Gibbs, 2000), it is a reasonable assumption that for both graduates and employers, the goal of finding the best job, or the best candidate for the job, is paramount. The ability for firms to compete effectively on a global basis and operate successfully in export markets "hinges on the ability of today’s students” (CasnerLotto, 2006), yet across developed economies employers share similar common concerns about serious gaps in graduate skills (Jackson, 2010).

The need to align university curricula with the needs of employers has been noted by many (Davis et al., 2002; Karns \& Abraham, 2009; Jackson, 2014b), and yet academics “may be fuelling the skills gap”, because of a "lack of appreciation of contemporary workplaces by academics... (or their) limited experience... in the workplace” (Jackson \& Chapman, 2012, p. 108-109). Other researchers found that academics believed "recruitment was not considered important because it was not deemed to be an academic responsibility” (Gibson-Sweet et al., 2010, p. 937). In marketing education especially, the need for continuous improvement in academic curricula becomes crucial in a field that is rapidly changing because of the growth of digital and social media marketing, and new technologies and channels. Yet there is a 
“disconnect between marketing education and marketing practice” (Harrigan \& Hulbert, 2011, p 253).

The competitive nature of graduate employment, and a perception that a university degree provides undifferentiated outcomes to more vocational education (Kirp, 2003), raises the question: Why undertake a university degree if there are faster or cheaper routes to equivalent jobs? This question is amplified against the upsurge of competition in higher education, including private for-profit providers, and the advent of massive open online courses, such as those offered by Coursera, edX, and Udacity. In the face of this rising competition, universities and academics must become more accountable for their outputs, and indeed, throughout the academic world, employability has been "firmly entrenched in higher education's strategic agenda worldwide” and "academics must acknowledge the futility of resisting the skills movement as governments in developed economies continue their strategic focus on skill outcomes through, among other initiatives, national skill frameworks and conditional funding rules” (Jackson 2014, p.223).

This study aims to identify, through the content analysis of job advertisements, the specific skills and attributes demanded by employers from candidates seeking graduate marketing jobs in Australia. While the data for this research have been collected in Australia, the findings of this study may be transferable across other developed economies. This is because of the increasingly global nature of business activity, and the internationalisation of academic curricula world-wide via such initiatives as Europe's Bologna process (Pavlin \& Svetlik, 2014). The following literature review further expands on the need for this study by highlighting some important limitations of a still immature body of research, including the limited focus on employers, and the dominance of survey methods. 


\section{Literature review}

The extant research on graduate employability can be clustered into four areas: definitional literature that reflects the newness of this field of study, defining such terms as “soft skills”, “competencies”, and “work-ready” (Cornford, 2005; Barrie, 2007; Tomlinson, 2012; Williams et al., 2015); a smaller body of work on curriculum development to address employers’ needs (Bascoul et al., 2013; Brennan \& Vos, 2013; Jaskari \& Jaskari 2016; Spiller \& Tuten, 2015; Taylor, 2003; Treleaven \& Voola, 2008); factor analyses of employability skills (Gow \& McDonald, 2000; Finch et. al, 2012; Barker, 2014; Jackson 2014); and gap analyses of the discrepancies between teaching and practice (Stringfellow et al., 2006; Martin \& Chapman, 2006; Jackson \& Chapman, 2012). Two examples of gap analyses are by Stringfellow et. al (2006, p.252), who "clearly identified deficiencies in the area of practical skills”, and Jackson \& Chapman (2012), who found significant differences between academics and employers in their perceptions of business graduates on the variables of “commercial awareness”, “drive”, “project management”, and “decision making”.

\section{Graduate Employability Research in Australia}

Extant research focuses on business graduates as one combined cohort, and is almost entirely nonspecific to marketing. In addition, the UK and USA dominate the employability literature, and scholarly work from other parts of the world is lacking, including Australia. The two most prolific Australian authors are Denise Jackson (for example, 2010, 2014, 2014b, 2016), and Stephen Billett (for example, 2013, 2014, 2015), who advocates for far greater vocational orientation in higher education. Other Australian contributors include Treleaven and Voola (2008), who recommended "graduate attributes are expressed as learning outcomes and aligned with assessment criteria” (p. 160), and McDonald and Gow (2000), whose factor analysis study found four attributes could increase employment 
prospects: adaptability to changing work environments, cross-cultural competence, accountability, and business management skills. Of the Australian works, only two papers examine marketing in particular: a study of 59 marketing course profiles to assess their alignment with eight preselected employability skills (Rundle-Thiele et al. 2005), and a gap analysis that found "basic but critical gaps” in graduate skills (Walker et. al, 2009, p.261).

\section{Limitations of Graduate Employability Research}

Because graduate employability is an emerging field of study, nascent knowledge still has some major deficiencies. First, is the substantial dominance of survey methods, for example, Aistrich et al., 2006; Allen et al., 2014; Azevedo et al., 2012; Ellen \& Pilling, 2002; Finch et al., 2012; Hodges \& Burchell, 2003; Hyman \& Hu, 2005; Jackson 2014; Jackson \& Chapman, 2012; Karns \& Abraham, 2009; Kelley \& Bridges 2005; McDonald \& Gow, 2000; Martin \& Chapman, 2006; Nair \& Mertova, 2009; Stephens et al., 2010; Wittekind et. al, 2010. Surveys have the limitation of confining responses - and therefore the nature of the possible findings - to variables selected by researchers. This results in a closed-loop process of knowledge advancement where a finite set of variables used in other people's work is tested repeatedly.

A corollary weakness of surveys is the focus on general skills such as teamwork, communication, autonomy, and problem-solving, which are variables that slot easily into surveys despite their indistinctness (Jackson, 2014b). Perceptions on the relative importance of these “soft skills” varies (Walker et al., 2009), but these are common attributes expected of any university graduate, and they appear fairly consistently "across several developed economies” (Jackson, 2014, p.221).

Another shortcoming of extant knowledge relates to sample selections. While employers are arguably the key stakeholder, their voice is absent from the sampling frame in many 
studies. Instead, the samples include students (Huang et al., 2014; Berman \& Ritchie, 2006), alumni (Davis et al., 2002), academics (Gibson-Sweet et al., 2010), marketing course outlines (Rundle-Thiele et al., 2005), recruiters and résumés (Barr \& McNeilly, 2002; Weeks et al., 2014), and career services (Farenga \& Quinlan, 2015).

\section{Content analysis of employment advertisements}

Aside from surveys, there is a far smaller number of studies employing other methods, including case studies (Helyer \& Lee, 2014), in-depth interviews (Harrigan \& Hulbert, 2011; Resnick et al., 2011; Walker et al., 2009), mixed methods (Finch et al., 2013; Martin \& Chapman, 2006 Farenga \& Quinlan, 2015), and two UK studies that stand out because of their use of content analysis of employment advertisements (Wellman, 2010; Bennett, 2002). Content analysis of job advertisements overcomes the weakness of surveys, with preselected variables, by studying how employers explicate their needs, untrammelled by the assumptions of researchers.

Bennett (2002) analysed 1,000 job advertisements in four occupations (general management, finance, human resource management, and marketing), and Wellman (2010) focused on 250 job ads for entry-level marketing positions in the UK. Bennett's focus was on differences across occupational categories, finding that "advertisements for marketing and general management jobs were significantly more likely to demand initiative, motivation, and communication skills... (and) more prone to require IT and presentation skills” (Bennett, 2002, p. 470). Wellman's study is valuable for its focus on marketing specifically but it is limited by its UK scope, and aged data (2008-2009) in a discipline that is rapidly evolving because of the rise of electronic marketing.

In the USA, Schlee \& Harich (2010) content analysed 100 marketing jobs for each of five metropolitan areas, but their focus was on the relative demand for "conceptual knowledge" 
versus “technical skills”, for entry and lower level jobs, compared with middle to upper level positions. Content analysis has also been used in sub-fields of marketing, including sponsorship jobs in America (Diamond et al., 2014), professional communication positions in Sweden (Rosén, 2014), and event management jobs in Australia (Arcodia \& Barker, 2002). The latter is the only known Australian research of job ads in a field related to marketing, although that study takes a tourism industry viewpoint, and is limited to 105 advertisements.

As a data source for studying employability, large samples of employment advertisements are possibly the most valid source for research, and though many thousands of job ads are published every day, "these apparently small and trivial texts have, so far, not created much interest within social science” (Rosén, 2014, p. 18). Yet job advertisements portray perceptions of the ideal applicant and (in order to attract the best candidates), and the ideal company (Rafaeli \& Oliver, 1998), and provide "a social construction that responds to institutionalized conceptions about a profession and... its meaning in different contexts" (Rosén, 2014, p. 17). While Rafaeli \& Oliver (1998) acknowledge that job ads may reflect the culture in which the ad is published, or the society to which the employer institution belongs, their global study draws on job advertisements from five different English-speaking countries, with no cultural differences noted in the content of job ads.

Because definitions and terminology in the employability field are still being debated and the data in this study are dictated by employers, this paper refrains from offering any formal definitions. Informally, however, we align with the conception of "employability" offered by Huang et al. (2014), as “an individual's potential to gain and maintain employment within the current labour market”. Because the labour market is constantly in flux, and also subject to both relative and absolute pressures of supply and demand (Morrison, 2014), this conception implies a willingness to continuously develop new competencies and employability skills. 


\section{Research method}

This study follows the methodology used by two UK researchers, Bennett (2002) and Wellman (2010), who content analysed job advertisements. For this study, the data consists of advertisements downloaded from the internet for entry-level marketing jobs in Australia. This method is appropriate for a national study because it captures data from a population of employers who were dispersed over large and otherwise unreachable distances.

Since this study is exploratory, the research aim was deliberately broad: essentially to identify and rank the particular skills and attributes demanded by employers of graduates seeking work in marketing in Australia. The research question was:

What are the specific skills and attributes employers want in candidates for graduate marketing jobs in Australia?

Because the data would depend on the search terms and websites used, this study proceeded in three rounds. The first aimed to identify Australian job websites from which the data could be collected, and their available search filters. After comparing the search results on 13 websites, it became apparent that seek.com.au contained the highest number of jobs, and that jobs on rival sites also appeared there. The data was therefore collected from seek.com.au, the largest employment site, which hosts approximately 160,000 job ads per month, and 35 million monthly website visits in Australia and New Zealand (SEEK, 2016 Annual Report).

The data were captured over a two-day period in March 2016, and a second download took place six months later in September, providing two detached time points of data collection. This addressed the possibility of seasonal variations in types of jobs, and therefore the skill sets required for them. The search and capture method was identical on both occasions, and used the URL seek.com.au/graduate-jobs and the single keyword of 
“marketing”. This combination provided the highest number of jobs, including a long tail of irrelevant positions (for example, non-degree), but minimised the possibility that relevant roles might be excluded. Other search filter combinations were tested, including typical entrylevel salary brackets (A $\$ 30 \mathrm{~K}-\$ 60 \mathrm{~K})$, and common entry-level job titles or keywords (for example, “marketing assistant”, “marketing co-ordinator”, “brand”, “communications”), but these were found to be not sufficiently inclusive of all graduate-level entry jobs. The assortment of job title names in marketing is large and indefinite, and in Australia, remote location work attracts premium salaries far beyond the business graduate starting median of A $\$ 50 \mathrm{~K}$.

The final selection of a single keyword, "marketing", together with the seek.com.au/graduate-jobs URL, produced 1,132 job ads across all industries in March, and 1,287 ads in September. Of these 2,419 total ads, 1,417 did not specify the need for a degree and were discarded from the sample. (Their inclusion under the graduate-jobs URL results from an advertiser's choice when listing the ad. Although that choice implies graduates were preferred, there was no mention of a degree and thus, no exclusion of non-graduates.) Of the 1,002 remaining, other ads were eliminated because they were duplications, or posted by recruitment agencies. Agency ads were discarded because of their repetitive content, and therefore suspected use of templates for writing advertisement copy, which may have skewed the data. Thus, the final qualified sample totalled 359 job advertisements from 18 industry sectors, and 82,927 words of data. This averages at 231 words per ad, almost a page in length, and is one indicator of the high level of detail found in most job advertisements.

The final sample of 359 job advertisements was coded in NVivo by two researchers, and there was a high degree of coding consistency between them. Their coding was checked by the two other authors for accuracy and validity, and all discrepancies were discussed until consensus was reached. The discrepancies stemmed entirely from vagueness in written 
expression, for example, “work on a conceptual level and is also able to be pragmatic and results-oriented and perform hands-on change activities”, or "Respect for Human Rights and Emergency/Evacuation Procedure”. The finding of ambiguous and poorly worded advertisements supports the research of Mathews \& Redman (2001) in their cross-country study of 300 job ads. The authors found "at least some of the blame" for employer dissatisfaction with poor staff or the wrong candidates being employed, could be attributed to the fact "that the advertisement itself is inappropriately constructed" (Mathews \& Redman, 2001, pp. 541-542).

A starting set of 14 nodes for coding of attributes was adopted a priori from the studies by Bennett (2002) and Wellman (2010), with reference and comparison to other literature in the field. In the process of checking and cross-checking the data, these a priori nodes were reduced in number, and emergent nodes also became apparent. This iterative process produced a final list of 13 parent nodes: Communication Skills, Numeracy, General IT Computer, Interpersonal, Problem-Solving, Analytical, Research and Information Gathering, Occupational, Administration, Tertiary Qualifications, Foreign Language, Work Experience, and Employee Attributes. Under these 13 parent nodes, there were 44 emergent and a priori child nodes, or sub-categories. The entire list of 49 nodes is presented in Table 1 . This set provides a depth of detail of double the number of variables in most studies, for example, the 20 skills used by Jackson \& Chapman (2012, p. 97), or 23 variables in Nair \& Mertova's paper (2009). A chi-square test was conducted on the two data batches and found no significant differences $(\mathrm{p}=0.423)$.

\section{Results}

The sample 
A qualified total of 359 graduate entry-level job advertisements were content analysed. Of this sample, full-time jobs constituted 87 per cent of the sample, part-time 7 per cent, 4 per cent contract positions, and 2 per cent casual roles. The jobs were posted by a total of 18 industry sectors, with 59 per cent from marketing, followed by sales (13 per cent), advertising (6 per cent), administration (5 per cent), and to lesser extents, design, education, information and communication, real estate, and banking.

It was not possible to readily discern the size or major business activity of the employer institutions - for example B2B or B2C, large or small-to-medium (SME), not-for-profit (NFP), or government - and therefore categorisation by type was not attempted. Research to determine the nature and size of those businesses could have shed further light on the data, but was outside the scope of this project.

In terms of the geographical distribution of jobs, 76 per cent of positions $(n=271)$, were located in Australia's two largest states, New South Wales and Victoria, and almost all of these jobs were located in their capital cities, Sydney and Melbourne. The aggregation of work opportunities in large cities is not surprising, but this high level of concentration reveals a poor fit with Australia's population distribution. While 76 per cent of jobs are located in the two largest centres, their State-wide populations constitute only 57 per cent of total (ABS 2016). This implies that a precondition for being "work-ready" in Australia, with only 24 million scattered around the sixth largest country on earth, is a readiness to relocate.

Interestingly, a marketing degree (which is typically completed in Australia after three years full-time study), was specified in only 50.4 per cent of the jobs $(n=181)$. Around one in five ads specified a degree in business or commerce $(n=72)$, closely followed by communications degrees ( $n=68)$. Nearly one in four listed other discipline degrees $(n=86)$, including psychology, statistics, economics, engineering, computer science, education, or politics. This reflects the plurality and cross-disciplinary nature of marketing careers in the 
twenty-first century, bridging science, arts and humanities (ABDC, 2011), and where broad knowledge and skills rather than specialist qualifications are valued. It also suggests the need for collaboration with other academic disciplines for access to, or tailoring of, their content knowledge and courses.

Consistent with other research (Wellman, 2010; Martin \& Chapman, 2006), previous work experience was highly valued, with slightly less than half the ads ( $n=174)$ requesting applicants with experience. This is a substantial ratio and suggests the need for far greater integration of undergraduate study with initiatives that deliver hands-on practice, including work integrated learning and internships. Employers were often looking for candidates with one to three years of experience in roles including sales and sales support, digital marketing and social media, customer service, communications, research, and general marketing experience. While university curricula cover most of these areas targeted by employers, lack of practical experience may limit the competitiveness of job seekers.

The following section addresses the research question set for this study: What are the specific skills and attributes employers want in candidates for graduate marketing jobs in Australia? For ease of discussion, the characteristics are clustered under three main types: generic, personal, and occupational.

\section{Generic skills demanded by employers}

Generic skills, as implied by their name, are not specific to marketing, and include the core or key skills "beyond disciplinary content knowledge, which are applicable in a range of contexts and are acquired as a result of completing any undergraduate degree” (Barrie, 2007 p. 440). The findings in this study support the top six attributes found in Bennett's research (communication, IT, organisation, teamwork, interpersonal, and motivation), and also the top 
synonymous variables in Wellman's (2010) study (being organised, communication skills, IT, and teamwork).

The most frequently demanded ability was for superior communication skills, particularly writing $(n=152)$, and verbal proficiency $(n=126)$. The need for writing talent was repeated throughout the data for a wide range of genres including blogs, social media, websites, flyers, and newsletters for both internal and external audiences. This signals a serious syllabi shortfall, since marketing courses often cultivate only business writing skills, and writing remains a by-product, rather than the focus. This suggests the need for subjects that teach writing skills as the key learning outcome, to provide practice particularly in the informal conversational styles needed for social media, blogs, and webinars. Other authors have also argued for writing courses to be developed for the marketing curricula (West, 2006; Bacon \& Anderson, 2004), and there appear to be embarrassing deficiencies in graduate writing skills. The employers in one study (Stringfellow et al., 2006, p. 248) felt that the written work of their new graduate recruits "had to be checked for basic spelling mistakes". Academics would know that feeling of doubt is well founded. Similarly, a gap analysis found basic deficiencies in graduate writing skills, including "how to write corporate emails” (Walker et. al, 2009, p.261). Communication skills in all its forms are paramount for marketing jobs, as captured in this typical quote from one ad: "Excellent customer service and communication skills as you will be dealing closely with the press, suppliers, retailers, staff and the general public.”

Consistent with Bennett (2002), general IT skills and a high level of computer literacy emerged as important pre-requisites for applying for marketing positions. Experience in MS Office ( $n=113$ ), including Word, Excel, and PowerPoint, was specified in almost one in every three ads, followed by Adobe Suite software $(n=62)$, InDesign, Illustrator, and Photoshop. Though undergraduates might use these programs ad hoc, such strong demand levels suggest the need to embed the use of, and perhaps training for, such software into the curricula as 
specific learning outcomes. Evidence of competency in these IT programs would provide valuable additions to the graduate's work readiness.

The next most demanded attributes cluster around interpersonal abilities, including teamwork $(n=110)$, capability to network and establish business relationships $(n=99)$, and interpersonal skills ( $n=73$ ), and this is similar to the findings of other studies. For example, Finch et al. (2013, p. 681) found employers place "the highest importance on soft skills and the lowest importance on academic reputation”, though others have found the institution of study does make some difference on employability pathways (Li \& Miller, 2013).

General administrative tasks $(n=86)$ were specified in almost one in four job ads, with such chores as document control, and other duties that graduates might find less glamorous than expected. This suggests a willingness to adapt to base level office chores is a condition for being work-ready and, indeed, adaptability was one of the most highly demanded personal qualities. The sometimes tedious nature of job duties deserves attention and discussion, especially with today's younger students, a cohort that has been characterised as having an inflated sense of self-importance and entitlement, and unrealistic expectations of career advancement (Jackson 2010).

The strong demand for administrative skills, MS Office ( $\mathrm{n}=113$ ), and also general IT competence ( $\mathrm{n}=112)$, may reflect a high ratio of institutional types where employees need to be "all-purpose", for example, SME or NFP enterprises. Although we did not investigate the size or main business activity of the employer advertiser, the need for all-purpose employees was also suggested in descriptions such as: "Have knowledge of marketing trends and how they can be employed”, or “A good sense of business, particularly in marketing”. The demand for all-rounders and basic office work skills also raises questions about what we teach in marketing. As Martin \& Chapman found (2006, p.158), “graduates’ frame of reference is the world of big FMCG business; they do not understand the modus operandi of SMEs”, with 
SME proprietors remaining "sceptical about whether graduates really meet their needs". On the opposite side of the exchange, "graduates across disciplines have been unaware of what SMEs have to offer, and have perceived an attractiveness barrier” (Martin \& Chapman 2006, p.158, 161-162). This suggests the need for broadening academic curricula beyond the adulation of big businesses, to correct this bias, and raise awareness and upgrade the status of smaller enterprises.

Other general abilities such as analytical skills $(n=54)$, problem solving $(n=41)$, and creativity ( $\mathrm{n}=35$ ) were specified in far fewer ads than the demand for communication talent and IT skill, but recall that these were entry-level positions. Tasks such as problem solving and analysis might suggest more senior staff delegations. Surprisingly, for a nation of high linguistic diversity where almost 400 languages are spoken (ABS, 2009-10), only five advertisements required an ability to speak a foreign language, with Cantonese, Korean and Vietnamese being most demanded, mirroring Australia's proximity and integration into the Asian basin.

\section{Personal attributes demanded by employers}

Personal attributes include traits or qualities that characterise a person, either innate or learned, but typically not taught at university. Setting aside the generic skill of communication capabilities, these personal traits were in far greater demand than anything else. In descending order of prevalence, these were: motivation ( $n=230)$, time management ( $n=146)$, attention to detail $(n=116)$ and, related to motivation, a positive attitude $(n=98)$. Employers used descriptors such as "self-motivated”, “proactive”, “driven to achieve”, and "highly motivated to be successful".

Time management and the ability to multitask were also valued, as captured in these typical quotes: "Highly organised and able to effectively prioritise work and meet deadlines 
without sacrificing professional standards"; and "Sound organising and coordinating skills, including the ability to work under pressure, and the capacity to deal with competing priorities and still be accurate and attentive to detail.”

Independence, or the ability to work unsupervised, was the next most demanded characteristic ( $\mathrm{n}=97)$, and typical advertising copy described job seekers who are "Able to work independently and take responsibility and ownership of projects and tasks”. The ability to work with limited supervision, and the qualities of being organised, multi-tasking and attentive to detail, support the work of other researchers, who argue the importance of metaskills such as organisation (Bennett, 2002; Wellman 2010), autonomy (Jackson, 2014b), and priority-setting (Finch et. al, 2012). Some of these competencies could be developed and assessed across university courses, especially since the importance of "soft" skills has been recognised by executives as equally important to occupational knowledge (Robles, 2012). Indeed, this research found such soft skills figure more frequently and are in higher demand than occupational skills, as discussed in the next sections.

\section{Occupational skills demanded by employers}

Entries in this category are representative of the marketing occupation because they use terminology or jargon that is specific to members of the occupation (Rafaeli \& Oliver, 1998). Overall, the data show the value of what we teach in marketing is vital and in demand, but they also highlight gaps, and the need to update and align university syllabi with the skills and experience required by employers. The results show similarities with the precedent studies by Wellman (2010) and Bennett (2002), but there were also major differences.

The main area of departure from Wellman's (2010) research is in the field, or the skills that are mostly identified as occupation-specific. Wellman's study included nil findings that could be readily identified as specific to marketing, except for "customer care”. In contrast, 
some seven years after Wellman's analysis, our data show that digital marketing is today's most sought-after occupational knowledge ( $n=113)$, and the range of specialist skills in the digital domain is now substantial and diverse, including Google Analytics and AdWords, web content management, search engine optimisation, creating and curating social media content for Facebook, Twitter, LinkedIn, Instagram and Snapchat, and email and SMS marketing campaigns. One typical ad required this range of skills and experience: "A strong understanding of and experience in a variety of social media platforms; Experience with SEO best practices, Google Ad Words and Google Analytics; Experience in website best practice and content management systems”.

Other demanded occupation-specific skills included marketing project management $(n=46)$, marketing communications $(n=40)$, sales $(n=34)$, customer service $(n=31)$, and related to this, customer relationship management $(n=21)$. Other advertisers asked for general marketing ability $(\mathrm{n}=41)$, which included descriptions such as knowledge of marketing principles, understanding of best practice marketing and emerging trends in marketing, as well as the ability to create and adapt content to a wide range of marketing communications tools and media. It is worth noting that, with the exception of digital marketing, occupational skills appeared less frequently overall than personal attributes and generic skills.

\section{Discussion and Conclusions}

The aim of this study was to identify the specific skills and attributes demanded by employers from candidates seeking graduate marketing jobs in Australia. The research provides valuable insights into attributes sought in graduates, and for higher education institutions across the English-speaking world, the data provide a rich field of ideas for updating and aligning university curricula with the skills required by employers. Two immediate subject areas of significant demand, but shortfall of supply in marketing syllabi, 
are for a range of distinct specialities emerging under the digital marketing umbrella, especially in social media (content creation, curation, platforms, research and management); and secondly, the demand for communication skills, particularly in writing. In the face of disconcerting evidence of graduate inadequacy in writing capability, but mainstream demand from employers, courses that focus on writing as the key learning outcome are needed. Alternatively, collaboration with journalism or other apt departments, for access to or tailoring of their writing courses, is recommended. Employers' demands for knowledge of digital and social media marketing is significant and extensive, but current course offerings are lagging and too non-specific to be of real value. Some promising endeavours in course development in these domains, however, include work by Brocato et al., (2015), Crittenden \& Crittenden (2015), and Spiller \& Tuten (2015).

The study contributes to the evidence of the multi-disciplinary character of a career in marketing in the twenty-first century, where degrees in science, technology, engineering, mathematics, or property, sit alongside more expected disciplines of psychology, communications, and marketing (which was specified in only half the ads). This also suggests the need for more course and content alliances across disciplines, and the potential for more tailored and integrated marketing degrees, or perhaps for more vocationally-oriented education, as argued by many authors (for example, Billett 2013, 2014). Proficiency in general computing software, as one example of more vocational outcomes, was highly sought after, and formal evidence of competencies in Microsoft Office (including Excel), and Adobe Creative Suite could provide advantages for job seekers in marketing careers. Related to a more vocational orientation, the call for experience across a range of marketing areas was significant, including digital marketing, sales, customer service, communications, and work experience in general. This underlines the need for far greater integration of academic curricula with practical work-oriented experiences and placements, or assessment items that 
require and offer evidence of hands-on practice. Graduates today need to be not only qualified, but experienced, and the process of transition from university to the workforce could seem daunting.

The findings of this study show that both generic and personal traits are the most highly desired attributes, and it is only after the calls for communication skills, motivation, time management, and attention to detail, that occupationally-related skills begin to rank. These findings are consistent with other studies, and whether or not these qualities can be taught, deserves further research. At a minimum, students' awareness of the importance of these and other attributes that are of value to employers, needs to be developed. Students too have a role to play in closing the unemployment gap. That process should begin with their understanding of the factors in demand.

This study offers significant contributions in its methodology, data type, sample size, and geographic scope. Internationally, the research makes a contribution to the employability literature by building on an underused methodology that captures the explicit needs of employers. Job ads provide authentic data from the institution's viewpoint of what it means to be "work-ready", and shed light on corporate conceptualisations of the work done by marketers (Rafaeli \& Oliver, 1998; Rosén, 2014).

In terms of sample size, 359 marketing job advertisements, or almost 83,000 words, were downloaded and analysed. This sample size exceeds the UK precedent set by Wellman (2010) of 250 ads, and to the best knowledge of the authors, constitutes the largest body of job advertisement data collected specifically for the discipline of marketing. The study thus broadens our understanding of employability in marketing in particular, a field that has received scant focus thus far, and the key findings have relevance for graduates of all disciplines. The most frequently demanded attributes were personal and generic capabilities 
that are not specific to marketing, namely communication skills, motivation, time management, and attention to detail.

The study also expands the contributions of Australian scholars, a country that is underrepresented in the employability literature, despite the significance of higher education to its economy. Higher education is Australia's largest services export, and the country's third largest export overall (after coal, and iron ore), generating nearly A \$20b in 2014-2015 (DET, 2016). Though data are not available for marketing specifically, 60 per cent of international students in Australia study at a business school, and business education constitutes the largest of all academic disciplines, with 33 per cent of total university completions (ABDC, Key Facts, 2016). This study therefore contributes knowledge to Australia's most significant services export industry, and to the higher education sector's largest population by academic discipline. The study also contributes to the evidence supporting a more vocational orientation for higher education, in the findings of significant employer demand for experience. Finally, the research contributes to the growing body of employability literature as a collected whole. As described in the literature review, there are four discernible areas of scholarship: definition and terminology papers, factor analyses, gap analyses, and course development articles.

This study bridges over both factor and gap analyses knowledge, by naming the factors using the language of employers, rather than researchers. This contributes to terminology research and provides a starting point for further gap analyses using employer-dictated data. Applied to course development, the paper provides a discussion starter to review undergraduate courses - not merely in marketing - to bolster the integrity of content and outcomes, and build capacity for academics in becoming more accountable as a learning collegium to each other, to students, and to employers.

\section{Limitations}


This study has several limitations. First, possible bias arises from the reliance on a single data source. While searching advertisements on the internet was the most common strategy for job seekers in 2015 (26.9 per cent), it was not the only method of securing work (GCA, 2015 Gradstats). The seek.com.au site contained the highest absolute number of job ads of all employment websites in Australia, but subsequent studies might consider other sources, and also methods of securing jobs. Another caveat is that the language in job ads was sometimes ambiguous, limiting our certitude in interpreting some requirements. This flaw of vague language is common to all extant methodologies in employability research, although depth interviews offer the greatest promise of reducing this type of uncertainty.

Finally, limitations extend to acknowledging that there may be differences across different geographical or cultural contexts. One possible geographical difference stems from Australia's low population density, and thus a heightened need to be willing to relocate for work. Attitudes and needs of employers could also vary by country, along with the nature of jobs and the skill sets required for them. The value of a university degree is culturally dependent (Williams et al., 2015), as is the preference for - and status - of vocational education around the world (Billett, 2014). Cross-country research is recommended to build upon this exploratory study of Australian job advertisements for graduate level positions in marketing. 
Table 1.

\section{Coding variables and frequency (n) of desired attributes in graduate candidates for jobs}

\begin{tabular}{|c|c|c|c|}
\hline Parent nodes & Child nodes & $\mathbf{n}$ & Selected example quotes from job advertisements \\
\hline \multirow[t]{4}{*}{$\begin{array}{l}\text { Communication } \\
\text { Skills }\end{array}$} & Written & 152 & $\begin{array}{l}\text { Great writing; The ability to prepare a range of } \\
\text { professional written documents; Excellent writing, } \\
\text { editing and proofing skills }\end{array}$ \\
\hline & Verbal & 126 & $\begin{array}{l}\text { Strong verbal communicator; Ability to speak } \\
\text { succinctly and professionally; Effective communicator } \\
\text { amongst all levels of the organisation }\end{array}$ \\
\hline & Presentation Skills & 27 & $\begin{array}{l}\text { Strong presentation skills; Confident presentation } \\
\text { skills; High level of presentation }\end{array}$ \\
\hline & General & 95 & $\begin{array}{l}\text { Excellent communication skills; An experienced } \\
\text { communication professional; Clear and confident } \\
\text { communications skills }\end{array}$ \\
\hline \multirow[t]{9}{*}{$\begin{array}{l}\text { Employee } \\
\text { Attributes }\end{array}$} & Motivation & 230 & $\begin{array}{l}\text { Plenty of enthusiasm, self-motivation and drive to see } \\
\text { things through; A passion and flair for business and a } \\
\text { genuine excitement in building your career; highly } \\
\text { motivated }\end{array}$ \\
\hline & Time Management & 146 & $\begin{array}{l}\text { The ability to manage competing priorities and achieve } \\
\text { desirable outcomes within set time frames; Ability to } \\
\text { multitask, organise time, manage diverse activities and } \\
\text { meet deadlines; Outstanding organisational/time } \\
\text { management skills and the ability to focus and } \\
\text { prioritize }\end{array}$ \\
\hline & Attention to Detail & 116 & $\begin{array}{l}\text { Excellent attention to detail; You will have an eye for } \\
\text { detail; High level of accuracy and attention to detail }\end{array}$ \\
\hline & Attitude & 98 & $\begin{array}{l}\text { ‘Can do’ attitude; Good attitude of learning and } \\
\text { working w/others }\end{array}$ \\
\hline & Independence & 97 & $\begin{array}{l}\text { Work independently \& proceed with objectives without } \\
\text { supervision; Extremely proactive; You must be able to } \\
\text { autonomously manage your workload and projects }\end{array}$ \\
\hline & Adaptability & 31 & $\begin{array}{l}\text { Ability to adapt to change; Able to operate in complex } \\
\text { and ambiguous circumstances; Demonstrated } \\
\text { flexibility; A willingness to work in a varied role and } \\
\text { take on new challenges as required; Ability to adapt to } \\
\text { changing environments and work structures in a } \\
\text { growing company; Be available for occasional } \\
\text { interstate travel and qualitative research events on some } \\
\text { evenings }\end{array}$ \\
\hline & Work Ethic & 28 & $\begin{array}{l}\text { A strong work ethic; Punctuality and strong work ethic } \\
\text { required }\end{array}$ \\
\hline & Confidence & 27 & $\begin{array}{l}\text { Self-confident: knows own ability; High level of } \\
\text { confidence; Confident and decisive }\end{array}$ \\
\hline & Other & 112 & $\begin{array}{l}\text { Smiley, caring and absolutely committed; An interest } \\
\text { in the world of animation, film, TV, advertising and } \\
\text { video games; Confidential about the company's internal } \\
\text { operations }\end{array}$ \\
\hline \multirow{6}{*}{$\begin{array}{l}\text { Tertiary } \\
\text { Qualifications }\end{array}$} & Marketing & 181 & \\
\hline & Business or Commerce & 72 & \\
\hline & Communications & 68 & \\
\hline & Psychology & 6 & \\
\hline & Not specified & 54 & Bachelor degree; Recent university graduate \\
\hline & Other Degree & 86 & Degree in Event management or relevant business \\
\hline
\end{tabular}




\begin{tabular}{|c|c|c|c|}
\hline & & & $\begin{array}{l}\text { discipline; Tertiary qualification ideally in a Property } \\
\text { discipline; Tertiary qualification in science, technology, } \\
\text { engineering or mathematics }\end{array}$ \\
\hline \multirow[t]{9}{*}{ Occupational } & Digital Marketing & 113 & $\begin{array}{l}\text { Experience using Google Analytics to monitor online } \\
\text { engagement and recommend modifications to drive } \\
\text { continual improvement; Significant experience in } \\
\text { understanding digital marketing, web content } \\
\text { management and social media platforms; Strong grasp } \\
\text { of online marketing channels with experience planning } \\
\text { and implementing e-marketing campaigns from SEO, } \\
\text { SEM, email and banner to latest web related channels } \\
\text { for webinar, blog, and YouTube Channels }\end{array}$ \\
\hline & Project Management & 46 & $\begin{array}{l}\text { Excellent project management skills; Direct any } \\
\text { marketing and new project developments to include } \\
\text { public relations and community outreach; Manage } \\
\text { projects in line with client objectives and co-ordinate } \\
\text { all aspects to ensure project delivery in a timely manner }\end{array}$ \\
\hline & General Marketing & 41 & $\begin{array}{l}\text { A demonstrated understanding of business, marketing } \\
\text { and digital strategy, including the core methods and } \\
\text { principles; Strong ability to manage and develop } \\
\text { marketing activities; Develop strategies and plans } \\
\text { which identify marketing opportunities }\end{array}$ \\
\hline & $\begin{array}{l}\text { Marketing } \\
\text { Communications }\end{array}$ & 40 & $\begin{array}{l}\text { Proven experience writing and executing effective } \\
\text { campaigns with accuracy; Demonstrated ability to use } \\
\text { media for media releases, newsletters, brochures and } \\
\text { flyers; Demonstrated experience in marketing planning } \\
\text { and campaign development }\end{array}$ \\
\hline & Sales & 34 & $\begin{array}{l}\text { Exemplary history of excellent sales skills; Liaise and } \\
\text { interact with Marketing and Sales manager to identify } \\
\text { and drive campaigns to create revenue; Commercial } \\
\text { sales ability }\end{array}$ \\
\hline & Customer Service & 31 & $\begin{array}{l}\text { Strong customer service orientation; Enjoy delivering } \\
\text { superior customer service; Excellent customer service } \\
\text { skills }\end{array}$ \\
\hline & $\begin{array}{l}\text { CRM } \\
\text { (Customer } \\
\text { Relationship } \\
\text { Management) }\end{array}$ & 21 & $\begin{array}{l}\text { Demonstrated experience and proficiency monitoring, } \\
\text { maintaining or planning around CRM platforms; Client } \\
\text { management abilities, preferably to the advertising and } \\
\text { agency marketplace; Previous exposure to a CRM } \\
\text { (database) such as Salesforce, V-tiger, Microsoft CRM } \\
\text { is a big advantage to securing this role }\end{array}$ \\
\hline & $\begin{array}{l}\text { B2B (Business to } \\
\text { Business) }\end{array}$ & 3 & $\begin{array}{l}\text { B2B selling ability; Exposure to B2B sales; B2B } \\
\text { marketing experience in a similar role }\end{array}$ \\
\hline & Other & 38 & $\begin{array}{l}\text { General understanding and use of Nielsen products and } \\
\text { services; Experience in dealing with not for profit } \\
\text { associations and conference committees; Experience in } \\
\text { managing the tender/submission writing processes }\end{array}$ \\
\hline \multirow[t]{4}{*}{$\begin{array}{l}\text { Work } \\
\text { Experience }\end{array}$} & Digital Marketing & 52 & $\begin{array}{l}2 \text { years (or more) experience in Digital Marketing; } 1 \\
\text { year experience in social media planning, development } \\
\text { and management }\end{array}$ \\
\hline & General Marketing & 44 & $\begin{array}{l}\text { 2-3 years’ experience in marketing or fundraising } \\
\text { would be highly regarded; } 2 \text { years' experience in a } \\
\text { marketing position }\end{array}$ \\
\hline & Sales & 43 & $\begin{array}{l}\text { 2-3 years of experience in a similar sales support or } \\
\text { marketing role would be highly desirable; Previous } \\
\text { experience in a proactive sales \& marketing } \\
\text { environment within the hospitality/events/catering } \\
\text { sector ( } 2-3 \text { years desirable) }\end{array}$ \\
\hline & Customer Service & 27 & Experience in customer service; Relevant experience in \\
\hline
\end{tabular}




\begin{tabular}{|c|c|c|c|}
\hline & & & a customer-facing environment \\
\hline & $\begin{array}{l}\text { Marketing } \\
\text { Communications }\end{array}$ & 21 & $\begin{array}{l}\text { 1-3 years’ proven experience in a Communications role } \\
\text { is a MUST; At least } 2+\text { years' experience in a similar } \\
\text { communications and/or marketing role }\end{array}$ \\
\hline & Other & 85 & $\begin{array}{l}\text { 1-2 years research experience; } 2-3 \text { years data analyst } \\
\text { experience }\end{array}$ \\
\hline & Not Specified & 25 & 1-2 years commercial experience \\
\hline \multirow[t]{3}{*}{$\begin{array}{l}\text { General IT } \\
\text { Computer (non- } \\
\text { marketing) }\end{array}$} & MS Office & 113 & $\begin{array}{l}\text { Excellent Word, Excel and Outlook skills; Excellent } \\
\text { skills in Microsoft Excel and other Microsoft } \\
\text { applications are essential; Proficiency in Microsoft } \\
\text { Office applications }\end{array}$ \\
\hline & Adobe & 62 & $\begin{array}{l}\text { Sound knowledge of Adobe software, specifically } \\
\text { Photoshop (experience with Illustrator would be } \\
\text { beneficial); Adobe CS suite of tools including InDesign } \\
\text { and Photoshop (strong knowledge essential), } \\
\text { Illustrator, Fireworks and Dreamweaver; Strong } \\
\text { knowledge of Adobe Creative Suite: InDesign, } \\
\text { Illustrator and Photoshop }\end{array}$ \\
\hline & Other & 112 & $\begin{array}{l}\text { Ability to write code (e.g., SPSS syntax, JavaScript, R, } \\
\text { or any DP program); Experience with WordPress / } \\
\text { HTML / PHP; Smartphone applications }\end{array}$ \\
\hline \multirow[t]{3}{*}{ Interpersonal } & Teamwork & 110 & $\begin{array}{l}\text { Strong team-player; Proven ability to communicate } \\
\text { with management and teams across the organisation; } \\
\text { Work collaboratively with all team members across the } \\
\text { business to effectively share work in progress, plans, } \\
\text { ideas and resources }\end{array}$ \\
\hline & $\begin{array}{l}\text { Networking and } \\
\text { Business Relations }\end{array}$ & 99 & $\begin{array}{l}\text { Ability to foster positive relationships with external } \\
\text { suppliers, colleagues and team members; Demonstrated } \\
\text { experience coordinating and managing relationships } \\
\text { with a diverse range internal and external stakeholders; } \\
\text { Proven ability to establish and maintain positive } \\
\text { working relationships with all members of staff, } \\
\text { together with clients and suppliers }\end{array}$ \\
\hline & Interpersonal & 73 & $\begin{array}{l}\text { Strong inter-personal skills; High level interpersonal } \\
\text { and relationship skills }\end{array}$ \\
\hline \multirow[t]{3}{*}{ Problem Solving } & Problem Solving & 41 & $\begin{array}{l}\text { Strong problem solving and trouble-shooting skills; } \\
\text { Able to think clearly and rationally and problem solve } \\
\text { when the need arises; Able to solve problems } \\
\text { efficiently and effectively }\end{array}$ \\
\hline & Creativity & 35 & Develop creative solutions; Creative flair \\
\hline & Other & 6 & $\begin{array}{l}\text { Evidence of ability to design and implement processes } \\
\text { and strong operations background; Work on a } \\
\text { conceptual level and is also able to be pragmatic and } \\
\text { results-oriented and perform hands-on change activities }\end{array}$ \\
\hline $\begin{array}{l}\text { Administration } \\
\text { Tasks }\end{array}$ & & 86 & $\begin{array}{l}\text { Professional skills in support of committees and/or } \\
\text { boards; High level of organisational and administration } \\
\text { skills; Excellent organisational skills - must be } \\
\text { extremely organised and be able to keep calendars up } \\
\text { to date with launch dates, product availability }\end{array}$ \\
\hline Analytical & & 54 & $\begin{array}{l}\text { Strong analytical skills; Able to analyze and integrate } \\
\text { various data sources with market and industry } \\
\text { knowledge; Proven ability to analyse data \& draw } \\
\text { conclusions in order to develop strategy }\end{array}$ \\
\hline $\begin{array}{l}\text { Research and } \\
\text { Information } \\
\text { Gathering }\end{array}$ & & 42 & $\begin{array}{l}\text { Excellent skills in digital data gathering, analysis and } \\
\text { reporting; General market research techniques would } \\
\text { be an advantage; Working with questionnaires } \\
\text { including working with the data or being involved in } \\
\text { creating or updating questionnaires }\end{array}$ \\
\hline
\end{tabular}




\begin{tabular}{|l|l|r|l|}
\hline Numeracy & 12 & $\begin{array}{l}\text { High numeracy skills; Strong numerical skills; the } \\
\text { ability to understand and work with financial tools }\end{array}$ \\
\hline $\begin{array}{l}\text { Foreign } \\
\text { Language }\end{array}$ & 5 & $\begin{array}{l}\text { English and Chinese (Cantonese) essential, Vietnamese } \\
\text { an advantage; Ability to speak Korean is preferred as } \\
\text { required to contact Korean clients frequently }\end{array}$ \\
\hline
\end{tabular}




\section{References}

A. B. D. C. (2011). Academic standards for marketing in the Australian higher education sector (30 September). Marketing Learning Outcomes Working Party sponsored by the Australian Business Deans Council.

Australian Business Deans Council, Key Facts. (2016). Accessed 11 January, 2017. http://www.abdc.edu.au/pages/abdc-key-facts.html\#Reference11

A.B.S. Australian Bureau of Statistics (2016). Accessed 11 January, 2017. http://www.abs.gov.au/ausstats/abs@.nsf/mf/3101.0

A.B.S. Australian Bureau of Statistics (2009-2010), accessed 11 January, 2017. http://www.abs.gov.au/AUSSTATS/abs@.nsf/Lookup/1301.0Feature+Article32009\%E2\%80\%9310

Aistrich, M., Saghafi, M. M., \& Sciglimpaglia, D. (2006). Ivory tower or real world: Do educators and practitioners see the same world? Marketing Education Review, 16 (3), 73-80.

Allen, C., Kumar, P., Tarasi, C., \& Wilson, H. (2014). Selling sales: Factors influencing undergraduate business students' decision to pursue sales education. Journal of Marketing Education, 36 (2), 94-104.

Arcodia, C. V., \& Barker, T. (2002). A review of web-based job advertisements for Australian event management positions. Journal of Human Resources in Hospitality \& Tourism, 1 (4), 1-18.

Azevedo, A., Omerzel, D. G., Andrews, J., Higson, H., Caballero, A., \& Frech, B. (2012). Satisfaction with knowledge and competencies: A multi-country study of employers and business graduates. American Journal of Economics and Business Administration, $4(1), 23-39$. 
Bacon, D. R., \& Anderson, E. S. (2004). Assessing and enhancing the basic writing skills of marketing students. Business Communication Quarterly, 67(4), 443-54.

Barker, B. (2014). Employability skills: Maintaining relevance in marketing education. The Marketing Review, 14(1), 29-48. doi:10.1362/146934714X13948909473149.

Barr, T. F., \& McNeilly, K. M. (2002). The value of students' classroom experiences from the eyes of the recruiter: Information, implications, and recommendations for marketing educators. Journal of Marketing Education, 24(2), 168-173. doi:10.1177/0273475302242010

Barrie, S. C. (2007). A conceptual framework for the teaching and learning of generic graduate attributes. Studies in Higher Education, 32(4), 439-458. doi:10.1080/03075070701476100

Bascoul, G., Schmitt, J., Rasolofoarison, D., Chamberlain, L., \& Lee, N. (2013). Using an experiential business game to stimulate sustainable thinking in marketing education. Journal of Marketing Education, 35(2), 168-180.

Bennett, R. (2002). Employers’ demands for personal transferable skills in graduates: A content analysis of 1000 job advertisements and an associated empirical study. Journal of Vocational Education \& Training, 54(4), 457-476.

Berman, J., \& Ritchie, L. (2006). Competencies of undergraduate business students. Journal of Education for Business, 81(4), 205.

Billett, S. (2013). Towards a mature provision of vocational education. International Journal of Training Research, 11(2), 184-194. http://dx.doi.org/10.5172/ijtr.2013.11.2.184

Billett, S. (2014). The standing of vocational education: Sources of its societal esteem and implications for its enactment. Journal of Vocational Education \& Training, 66(1), 121. doi:10.1080/13636820.2013.867525 
Billett, S., \& EBSCOhost. (2015). Integrating practice-based experiences into higher education (2015th ed.). Dordrecht; New York; Springer. doi:10.1007/978-94-017$7230-3$

Brennan, R., \& Vos, L. (2013). Effects of participation in a simulation game on marketing students’ numeracy and financial skills. Journal of Marketing Education, 35(3), 259270. doi:10.1177/0273475313482928

Brocato, E. D., White, N. J., Bartkus, K., \& Brocato, A. A. (2015). Social media and marketing education: A review of current practices in curriculum development. Journal of Marketing Education, 37(2), 76-87. doi:10.1177/0273475315588110

Casner-Lotto, J. (2006). Are they really ready to work? Employers' perspectives on the basic knowledge and applied skills of new entrants to the 21st century U.S. workforce. United States: Alexandria, VA: Society for Human Resource Management.

Clarke, P., Gray, D. \& Mearman, A. (2006). The marketing curriculum and educational aims: Towards a professional education? Marketing Intelligence \& Planning, 24 (3), 189-201.

Cornford, I. (2005). Challenging current policies and policy makers' thinking on generic skills. Journal of Vocational Education \& Training, 57(1), 25-45. doi:10.1080/13636820500200273

Crittenden, V., \& Crittenden, W. (2015). Digital and social media marketing in business education: Implications for the marketing curriculum. Journal of Marketing Education, 37(2), 71-75.

Davis, R., Misra, S., \& van Auken, S. (2002). A gap analysis approach to marketing curriculum assessment: A study of skills and knowledge. Journal of Marketing Education, 24(3), 218-224. 
DET. (2016). The value of international education to Australia. Department of Education and Training. Accessed January 10, 2017. https://internationaleducation.gov.au/research/researchpapers/Documents/ValueInternationalEd.pdf

Diamond, K., Pierce, D., Johnson, J., \& Ridley, M. (2014). Content analysis of sponsorship sales job postings in the United States. Graduate Journal of Sport, Exercise \& Physical Education Research, 2, 19-36.

Ellen, P. S., \& Pilling, B. (2002). Using employer input to assess graduate marketing Education effectiveness: A working example of curriculum development. Marketing Education Review, 12(1), 31-40.

Farenga, S. A., \& Quinlan, K. M. (2015). Classifying university employability strategies: Three case studies and implications for practice and research. Journal of Education and Work, 29(7), 767-21. doi:10.1080/13639080.2015.1064517

Finch, D., J. Nadeau, \& N. O'Reilly. (2012). The future of marketing education: A practitioner's perspective. Journal of Marketing Education, 35(1), 54-67.

Finch, D., Hamilton, L. K., Baldwin, R., \& Zehner, M. (2013). An exploratory study of factors affecting undergraduate employability. Education+Training, 55(7), 681-704.

Gibbs, T. (2000). Isn't higher education employability? Journal of Vocational Education \& Training, 52(4), 559-571. doi:10.1080/13636820000200138

Gibson-Sweet, M., Brennan, R., Foy A., Lynch, J., \& Rudolph, P. (2010). Key issues in marketing education: The marketing educators' view. Marketing Intelligence \& Planning, 28(7), 931-43.

Graduate Careers Australia. (2015). GradStats. Retrieved from: http://www.graduatecareers.com.au/research/researchreports/gradstats/ 
Harrigan, P., \& Hulbert, B. (2011). How can marketing academics serve marketing practice? The new marketing DNA as a model for marketing education. Journal of Marketing Education, 33(3), 253-272. doi:10.1177/0273475311420234

Helyer, R., \& Lee, D. (2014). The role of work experience in the employability of higher education graduates. Higher Education Quarterly, 68(3), 348-372.

Hodges, D. \& Burchell, N. (2003). Business graduate competencies: employers' views on importance and performance. Asia-Pacific Journal of Cooperative Education, 4(2), 16-22.

Huang, R., Turner, R., \& Chen Q. (2014). Chinese international students’ perspective and strategies in preparing for their future employability. Journal of Vocational Education \& Training, 66 (2): 175-193. doi:10.1080/13636820.2014.894933

Hyman, M., \& Hu, J. (2005). Assessing faculty beliefs about the importance of various marketing job skills. Journal of Education for Business, 81(2), 105-110.

Jackson, D. (2010). An international profile of industry-relevant competencies and skill gaps in modern graduates. The International Journal of Management Education, 8(3), 2958. doi:10.3794/ijme.83.288

Jackson, D. (2014). Testing a model of undergraduate competence in employability skills and its implications for stakeholders. Journal of Education and Work, 27(2), 220-242. doi:10.1080/13639080.2012.718750

Jackson, D. (2014b). Skill mastery and the formation of graduate identity in bachelor graduates: Evidence from Australia. Studies in Higher Education, 41(7), 1313-20. doi:10.1080/03075079.2014.981515

Jackson, D. (2016). Re-conceptualising graduate employability: The importance of preprofessional identity. Higher Education Research \& Development, 35(5), 925-939. doi:10.1080/07294360.2016.1139551 
Jackson, D., \& Chapman, E. (2012). Non-technical skill gaps in Australian business graduates. Education + Training, 54(2/3), 95-113. doi:10.1108/00400911211210224

Jaskari, H., \& Jaskari, M. (2016). Critical success factors in teaching strategic sales management: Evidence from client-based classroom and web-based formats. Marketing Education Review, 26(3), 171-185. doi:10.1080/10528008.2016.1209973

Karns, L., \& Abraham, S. (2009). Do business schools value the competencies that businesses value? Journal of Education for Business, 84(6), 350-356. doi:10.3200/JOEB.84.6.350-356

Kelley, C. A., \& Bridges, C. (2005). Introducing professional and career development skills in the marketing curriculum. Journal of Marketing Education, 27(3), 212-218.

Kirp, D. L. (2003). Education for profit. Public Interest, 100+. Accessed 10 January 2017 http://go.galegroup.com/ps/i.do?p=EAIM\&sw=w\&u=griffith\&v=2.1\&it=r\&id=GALE \%7CA104136478\&asid=058d3144f0a3ea8736b5a25fc9901cdd

Li, I. W., \& Miller, P. W. (2013). The absorption of recent graduates into the Australian labour market: Variations by university attended and field of study. Australian Economic Review, 46(1), 14-30. doi:10.1111/j.1467-8462.2013.00713.x

McDonald, P., \& Gow, K. (2000). Attributes required of graduates for the future workplace. Journal of Vocational Education \& Training, 52(3), 373-396.

Martin, P., \& Chapman D. (2006). An exploration of factors that contribute to the reluctance of SME owner-managers to employ first destination marketing graduates. Marketing Intelligence \& Planning, 24(2), 158-73.

Mathews, B. P., \& Redman, T. (2001). Recruiting the wrong salespeople: Are the job ads to blame? Industrial Marketing Management, 30(7), 541-50.

Morrison, A. (2014). A class act? Lecturers' views on undergraduates’ employability. British Journal of Sociology of Education, 35(4), 487-505. 
Nair Sid, C., \& Mertova, P. (2009). Conducting a graduate employer survey: A Monash University experience. Quality Assurance in Education, 17(2), 191-203.

Pavlin, S., \& Svetlik, I. (2014). Employability of higher education graduates in Europe. International Journal of Manpower, 35(4), 418-424. doi:10.1108/IJM-05-2013-0104

Rafaeli, A. \&. Oliver, A. (1998). Employment ads: A configurational research agenda. Journal of Management Inquiry, 7(4), 342-58.

Resnick, S., Cheng, R., Brindley, C., \& Foster, C. (2011). Aligning teaching and practice: A study of SME marketing. Journal of Research in Marketing and Entrepreneurship, 13(1), 37-46. doi:10.1108/14715201111147932

Robles, M. M. (2012). Executive perceptions of the Top 10 soft skills needed in today’s workplace. Business and Professional Communication Quarterly, 75(4), 453-465.

Rosén, M. E. (2014). From ad-man to digital manager: Professionalization through Swedish job advertisements 1960-2010. Journal of Communication Management, 18(1), 16-39. doi:10.1108/JCOM

Rundle-Thiele, S., Russell-Bennett, R., \& Dann, S. (2005). The successful preparation and development of future marketing professionals: A recommended methodological framework. Journal for Advancement of Marketing Education, 7, 27-35.

Pefanis Schlee, R., \& Harich, K. R. (2010). Knowledge and skill requirements for marketing jobs in the 21st century. Journal of Marketing Education, 32(3), 341-352. doi:10.1177/0273475310380881

SEEK (2016). Annual Report. Accessed 25 April, 2017:

https://ir.seek.com.au/Investors/?page=Annual-Reports

Spiller, L., \& Tuten, T. (2015). Integrating metrics across the marketing curriculum: The digital and social media opportunity. Journal of Marketing Education, 37(2), 114-126.

Stephens, S., Camelia G B., \& Shaun C. (2010). Theory and practice: The experience of 32 
marketing graduates. Education + Training, 52(6/7), 552-60.

Stringfellow, L., Ennis, S., Brennan, R., \& Harker, M. J. (2006). Mind the gap. Marketing Intelligence \& Planning, 24(3), 245-256. doi:10.1108/02634500610665718

Taylor, K. A. (2003). Marketing yourself in the competitive job market: An innovative course preparing undergraduates for marketing careers. Journal of Marketing Education, 25(2), 97-107. doi:10.1177/0273475302250577

Tomlinson, M. (2012). Graduate employability: A review of conceptual and empirical themes. Higher Education Policy, 25(4), 407-431. doi:10.1057/hep.2011.26

Treleaven, L., \& Voola, R. (2008). Integrating the development of graduate attributes through constructive alignment. Journal of Marketing Education, 30(2), 160-173. doi:10.1177/0273475308319352

Walker, I., Tsarenko, Y., Wagstaff, P., Powell, I., Steel, M., \& Brace-Govan, J. (2009). The development of competent marketing professionals. Journal of Marketing Education, 31(3), 253-263.

Weeks, W. A., Rutherford, B., Boles, J., \& Loe, T. (2014). Factors that influence the job market decision: The role of faculty as a knowledge broker. Journal of Marketing Education, 36(2), 105-119.

Wellman, N. (2010). The employability attributes required of new marketing graduates. Marketing Intelligence \& Planning, 28(7), 908-930. doi:10.1108/02634501011086490

West, V. L. (2006). Teaching written communication skills in professional selling: The cover letter. Journal of Marketing Education, 28(3), 205-17.

Williams S., Dodd L., Steele C., \& Randall R. (2015). A systematic review of current understandings of employability. Journal of Education and Work doi: 10.1080/13639080.2015.1102210 
Wittekind, A., Raeder, S., \& Grote, G. (2010). A longitudinal study of determinants of perceived employability. Journal of Organizational Behavior, 31(4), 566-586. doi:10.1002/job.646 